Postprint version $\quad: 1.0$

Journal website $\quad:$ https://www.henw.org/artikelen/nieuw-onderzoek-naar-afbouwenantihypertensiva-bij-ouderen

Pubmed link

DOI

$10.1007 / \mathrm{s} 12445-019-0309-2$

This is a Nivel certified Post Print, more info at nivel.nl

\title{
Nieuw onderzoek naar afbouwen antihypertensiva bij ouderen
}

\author{
Dimokrat Hassan, Jorie Versmissen, Karin Hek, Liset van Dijk, Patricia van den \\ Bemt
}

\begin{abstract}
Ongeveer de helft van alle medicatiegerelateerde acute ziekenhuisopnames is potentieel te voorkomen. Van deze ziekenhuisopnames is $18 \%$ het gevolg van symptomen als syncope, vallen en duizeligheid. Deze symptomen zijn geassocieerd met het gebruik van (meerdere) antihypertensiva. Nieuw onderzoek van het Erasmus MC en het Nivel richt zich op de vraag of afbouwen van antihypertensiva bij ouderen het aantal ziekenhuisopnames door vallen en duizeligheid kan voorkomen en daarmee de kwaliteit van leven bij ouderen kan verhogen.
\end{abstract}

Doordat kwetsbare oudere patiënten vaak niet zijn vertegenwoordigd in onderzoeken waarop de richtlijnen zijn gebaseerd, is de behandeling met antihypertensiva in deze groep minder eenduidig dan bij jongere patiënten. ${ }^{1-4}$ Daarnaast zijn oudere patiënten over het algemeen vatbaarder voor bijwerkingen, waardoor ze een risicogroep zijn voor medicatiegerelateerde ziekenhuisopnames. ${ }^{2,3} \mathrm{De}$ kwetsbaarheid van deze patiënten is ook de reden dat de huidige NHG-Standaard Cardiovasculair risicomanagement (CVRM) een terughoudend beleid adviseert bij ouderen. ${ }^{3}$

Uit onderzoek blijkt dat voorafgaand aan de ziekenhuisopname van een oudere patiënt vaak reeds signalen, zoals duizeligheid, bekend waren bij de huisarts..$^{2-5}$ Bij deze patiënten zou een proces van verantwoord afbouwen van ongewenste antihypertensiva door een zorgprofessional uitkomst kunnen bieden.

In dit nieuwe onderzoek worden patiënten die in aanmerking komen voor het afbouwen van antihypertensiva geselecteerd met een klinische beslisregel. Deze regel selecteert patiënten met de volgende kenmerken: $>75$ jaar, gebruik meerdere antihypertensiva en ervaren mogelijke bijwerkingen gerelateerd aan antihypertensiva, zoals duizeligheid en vallen. Na selectie kan de huisarts, samen met de patiënt, bepalen of de medicatie daadwerkelijk wordt afgebouwd. De onderzoekers gaan ook na of het proces van afbouwen, een proces met veel belemmeringen in de praktijk, met shared decision making beter verloopt. Het hoofddoel van dit onderzoek is om na te gaan of het afbouwen van antihypertensiva leidt tot het verlagen van medicatielast en bijwerkingen (en ziekenhuisopnames) en wat voor effect dit heeft op de kwaliteit van leven van deze risicopatiënten. De resultaten worden verwacht in november 2020. 
Hassan, D., Versmissen, J. Hek, K., Dijk, L. van, Bemt, P. van den. Nieuw onderzoek naar afbouwen antihypertensiva bij ouderen. Huisarts en Wetenschap. 2019, 62(11), p. 94

\section{LITERATUUR}

De volledige literatuurlijst staat bij dit artikel op www.henw.org.

Hassan D, Versmissen J, Hek K, Van Dijk L, Van den Bemt PMLA. Nieuw onderzoek naar afbouwen antihypertensiva bij ouderen met een klinische beslisregel.

Huisarts Wet 2019;62(11):94. DOI:10.1007/s-12445-019-0309-2.

Erasmus MC, Ziekenhuisapotheek Rotterdam: D. Hassan, MSc, apotheker: d.hassan@erasmusmc.nl. Erasmus MC, Vasculaire geneeskunde, Rotterdam: dr. J. Versmissen. Nivel, Farmaceutische zorg, Utrecht: dr. K. Hek. Nivel/Rijksuniversiteit Groningen, Farmaceutische zorg, Utrecht/Groningen: prof.dr. ir. L. van Dijk. UMCG, Klinische Farmacie en Farmacologie, Groningen: prof.dr. P.M.L.A van den Bemt.

DEBATE-onderzoek: DEprescriBing Antihypertensives in The Elderly, using a clinical support system in general practice, www.deprescribe.nl.

Mogelijke belangenverstrengeling: niets aangegeven.

Dit is een bijdrage in de rubriek Lopend onderzoek, relevant voor de eerste lijn, geschreven door een promovendus. 